\title{
原著論文
}

スキーポール用 CFRP シャフトの強度に及ぼす衝撃損傷の影響†

$\begin{array}{lllllll}\text { 北 } & \text { 伀 二* } & \text { 風 } & \text { 間 } & \text { 武* 島 田 享 久* } \\ \text { 篠 原 } & \text { 昭** } & \text { 小 林 光 } \text { 征 }^{* * *} & & & \end{array}$

\section{Effect of Impact Damage on Strength of CFRP Shaft for Ski-Pole}

\author{
Shunji KITAZAWA*, Takeshi KAZAMA*, Takahisa SHIMADA* \\ Akira SHINOHARA** and Mitsuyuki KOBAYASHI***
}

\begin{abstract}
Evaluation of strength decreases of ski pole shafts made of carbon fiber reinforced plastics (CFRP shaft) caused by surface impact damage during skiing were investigated in both bending and post-buckling tests. Aluminum-alloy ski pole shafts (Al-alloy shaft) were also tested for comparison. Compared to non-damaged CFRP shafts, $50 \%$ decrease in bending fracture load and $80 \%$ decrease in post-buckling displacement were found after giving an impact load of about 1 joule to the surface of the shaft. This was assumed to be the amount given by actual collisions with ski plates during skiing. Observation by X-ray showed that the strength decrease was mainly caused by inner damage such as delamination of composite layers. On the other hand, the strength decrease of Al-alloy shaft was smaller. As with post-buckling, the compressive fracture occurred at the impact-damaged surface region in CFRP shafts, while in Al-alloy shafts conventional buckling fractures were observed. On the basis of results obtained, it was finally proposed that the tests employed in this study were suitable for estimating strength of CFRP shafts of ski poles.
\end{abstract}

Key words : Ski-Pole, CFRP Shaft, Impact Damage, Bending Strength, Post-Buckling

†原稿受付 1998年 3 月 3 日

1997年10月スポーツエ学シンポジウム1997にて発表

*長野県工業試験場

于380-0922 長野県長野市若里 188

**信州大学䋐維学部

于386-0018 長野県上田市常田 3-15-1

***信州大学工学部

于380-0922 長野県長野市若里500

*Industrial Research Institute of Nagano, 188, Wakasato, Nagano, Nagano, Japan (380-0922)

**Faculty of Textile Science and Technology, Shinshu University, 3-15-1, Tokita, Ueda, Nagano, Japan (386-0018)

${ }^{* * *}$ Faculty of Engineering, Shinshu University, 500, Wakasato, Nagano, Japan (380-0922) 


\section{1. 緒}

言

近年, 炭素繊維複合材料 (CFRP) 製のパイプ は，航空・宇宙機器やスポーツ用品など様々な 構造材料として使用されている。スポーツ用品 では，ゴルフシャフトや釣り竿に適用され，高 い比強度・比弾性の特色を生かした材料として 主流を占めてきたが，最近になってスキー用品 の一つであるスキーポール（スキーストック） のシャフト材料に，アルミニウム合金の代替材 料として使用されつつある。しかし，スキーポ 一ルの使用環境は他のスポーツ用品とは異なり, シャフトとスキーエッジの衝突など材料に直接 的な外力を受ける過酷な状況にあるため，材料 設計の概念にこのような衝撃荷重を考慮する必 要がある。衝撃荷重を受けた CFRPは，衝撃部 の繊維の破断や層間剝離といった衝撃損傷が発 生し，著しい材料強度の低下が起こることは， 繊維強化秷層板について多くの報告がなされて いる1). しかし, 直径 10 数 $\mathrm{mm}$ 程度の小径パイプ での衝撃損傢の特徵や残存強度についての報告 はあまり見られない。また，スキーポールに関 する規格 ISO7331-1983²においても，相当の評 価項目がなく，スキーポールの開発指針となり うる試験法が望まれている.

本論文では, スキーポール用 CFRP シャフト が使用中に受ける衝撃損傷の特徵と強度低下の 関係を明らかにするとともに，従来のスキーポ ール用アルミニウム合金シャフトの試験結果の 比較から, CFRP シャフトの特徵について報告 する，さらに，スキーポール使用時に見られる ポストバックリングの破壊現象から，スキーポ 一ルの基本的な試験法を提案する.

\section{2. 実 験 方 法}

\section{1 供試シャフト}

本実験で使用した CFRP 製シャフトの形状, 寸法を Fig. 1 に示す.スキーポール用シャフト は，ストレート部とテーパ部からなっている。 シャフトの肉厚は, $1.5 \mathrm{~mm}$ 一定で, マトリック スにエポキシ樹脂を使用したプリプレグをシー トワインディング法によって成形している.Table 1 にCFRP シャフトの材料構成を示す. CFRP シャフトとの比較実験に使用したアルミニウム 合金製シャフトは, 高力系7001材 $(\phi 18, \mathrm{t} 0.8)$ である。

\section{2 衝撃損傷の付与方法}

スキーポールのシャフトは，スキー滑走時に スキーエッジが衝突し，その衝撃によって損傷 を受けることが予想される。この現象を実験室

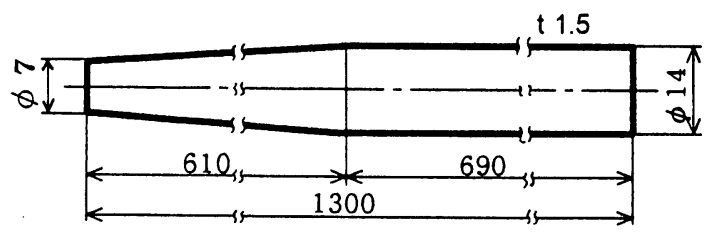

(a) Dimension

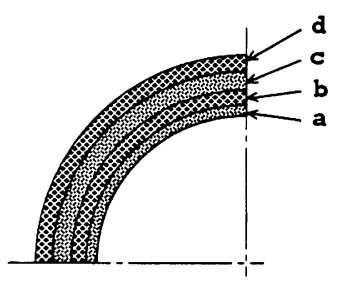

(b) Cross section

Fig.1 Geometry of CFRP shaft

Table 1 Material composed of CFRP shaft

\begin{tabular}{ccccc}
\hline Layer & Sheet & Thread & Ply Number & Resin \\
\hline a & T700WD & T700 & 1 & TORAY \#2500 \\
\hline b & T 300Cross & T 300-3000 & 2 & Original \\
\hline c & T700WD & T 700 & 3 & TORAY \#2500 \\
\hline d & T 300Cross & T 300-3000 & 3 & Original \\
\hline
\end{tabular}


において定量的に与える方法を Fig. 2 に示す. 衝撃の定量化は, デュポン式塗膜用落下衝撃試 験機を用い, 荷重点を $90^{\circ}$ (先端半径 $\mathrm{R}=0.1 \mathrm{~mm}$ ) にすることにより，シャフトの長手方向と直角 に損傷を与える。落下高さは最大で $0.5 \mathrm{~m}$ とし， 自由落下させる。落鍾は $1 \mathrm{~kg}$ を主に用い, 位置 エネルギーから求める衝撃エネルギーを高さを 変えることにより変化させ, 最大 5 ジュール $(\mathrm{J})$ とする．ただし，1 J 以下の場合については，落 錘を $0.3 \mathrm{~kg}$ と $0.5 \mathrm{~kg}$ とする.

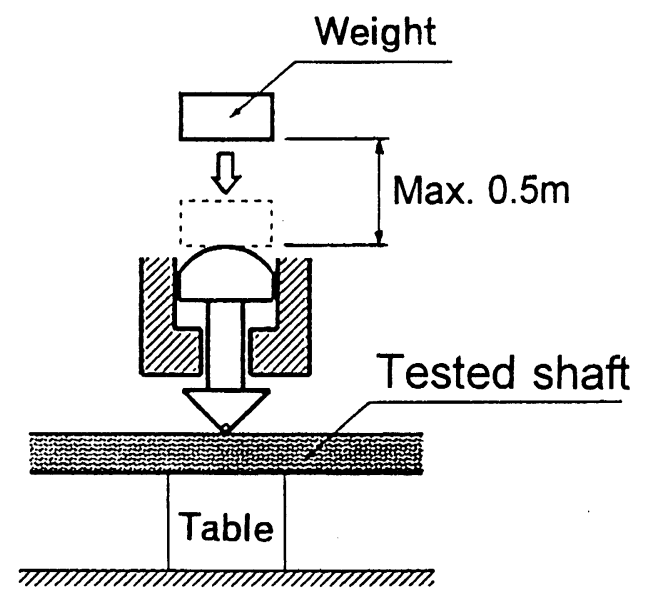

Fig.2 Schematic illustration of impact damage test

\section{3 衝擊損傷の評価方法}

Fig. 2 の方法により衝撃を付加したCFRP シ ヤフトの損傷の特徵は，外観評価と内部欠陥観 察により行う.

外観評価は，CFRP シャフトの衝撃個所表面 の形状を触針式の形状測定機で測定する．内部 損傷は，造影剂(1.4-ジョードブタン)を損傷部 表面から減圧含浸させた後，軟X線透過装置に よって印画紙に露光し観察する.

\section{4 強度低下の評価法}

衝撃付加による CFRP シャフトの強度低下は, インストロン型材料試験機（東洋ボールドウィ ン製 UTM-10T) を用い，Fig. 3 の曲げ試験方法 により評価する．曲げ試験では，負荷方法によ り破壊現象に影響することが考えられることか ら,Fig. 3 (a)に示すように損傷部分を荷重点半径 $50 \mathrm{~mm}$ の三点曲げ試験法と,Fig. 3 (b)のように荷重 点が損傷部分に接触しない四点曲げ試験を行う. ここで，三点曲げ試験と破壊荷重の比較を行う 場合，最大曲げモーメントが等しくなるように 荷重值の換算を行う。実験にはシャフト直管部 を使用し，支点間中央の圧縮側に損傷部分が位 置するように試料をセットする。

滑走中でのシャフトの軸線上に負荷が掛かる 場合を想定し, Fig. 4 に示すようなポストバック

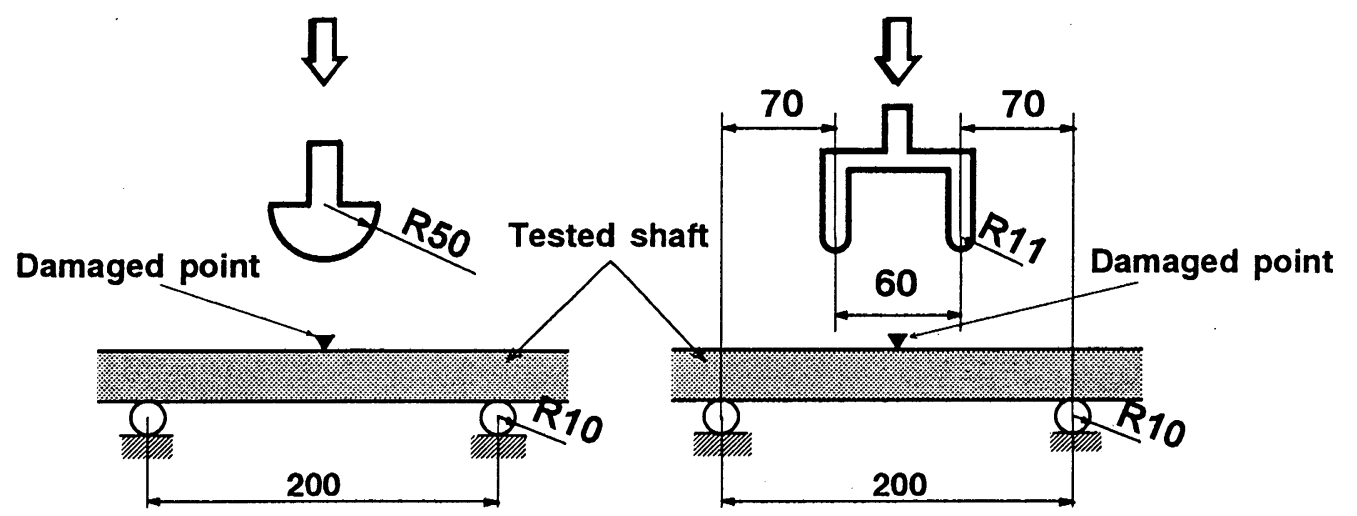

(a) 3 points bending

(b) 4 points bending

Fig.3 Methods of bending tests 


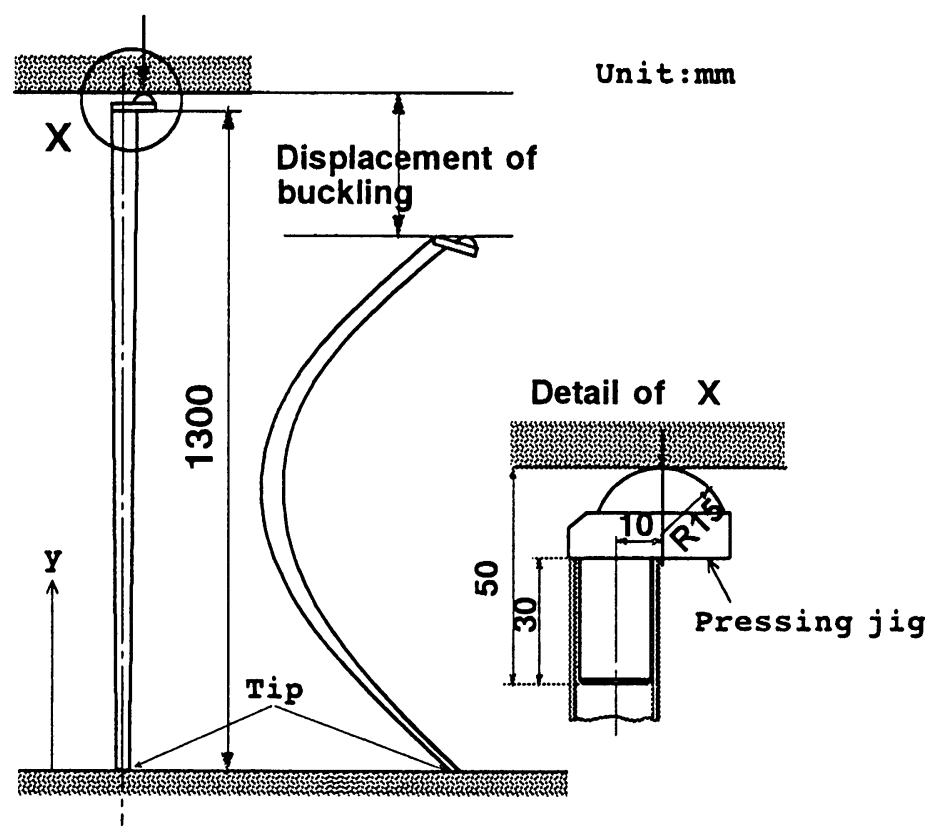

Fig.4 Method of post buckling test

リングによる破壊試験23)を行う。ポストバック

リング試験の両端の支持は, 石突き側を軸線上 とし，グリップ側を治具により軸線から $10 \mathrm{~mm}$ 偏 心させ, 荷重と変位の関係を求める. ポストバ ックリング試験のシャフトの挙動は, 高速ビデ オにて観察する。

\section{3. 実験結果および考察}

\section{1 衝撃損傢の特徵}

$1 \mathrm{~J}$ の衝撃エネルギーを加えたときの損傷の表 面形状の測定結果を Fig. 5 に示す。同図から, CFRP シャフトはアルミニウム合金シャフトに 比べ, 円周方向で荷重点による破壊の進展が大 きく，アルミニウム合金シャフトに見られる荷 重点周辺の緩やかな変形が見られない。また， 損傷近傍に折損によるバリが発生している.

2 種類のシャフトに付けられた損傷の特徵は, 衝撃エネルギーと損傷の最大深さから把握でき ると思われることから，その関係を Fig. 6 に示 す. 同図から, アルミニウム合金シャフトは衝 慗エネルギーの増加とともにその損傷深さも増 加している。この関係はシャフトの塑性変形も 含むことから, 衝撃エネルギーの増加に対し,

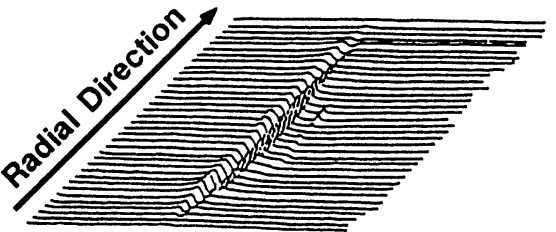

(a) CFRP shaft of $14 \mathrm{~mm}$ in diameter and $1.5 \mathrm{~mm}$ in thickness

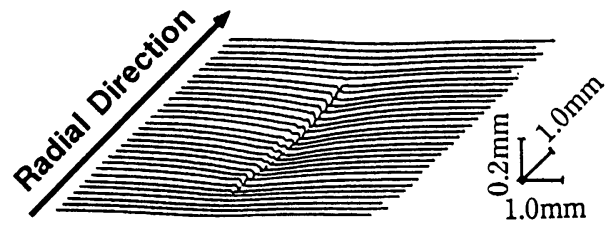

(b) Al-alloy shaft of $18 \mathrm{~mm}$ in diameter and $0.8 \mathrm{~mm}$ in thickness

Fig.5 Appearances of damaged surface measured with surface form tester

損傷深さがより大きくなっている.

これに対して，CFRP シャフトの場合には, 衝撃エネルギーが約 $3 \mathrm{~J}$ まで損傷深さが増加する のに対し，それを越えると損傷深さが一定とな っている。この理由として, 衝繋エネルギーが 約3J までは, 表面構成材料の破壊の進行によっ 
て損傷が深くなるが，それを越えると材料内部 の層間剝離によって衝撃エネルギーが吸収され ると推定される。

この破壊現象の把握は, CFRP シャフトへ $1 \mathrm{~J}$ から5J までの衝撃エネルギーを与えたときのX 線透過写真により比較する。その観察結果を Fig. 7 に示す。同図から, 衝撃エネルギーが増加す ると, 材料内部の破壊周辺部から層間剥離が進 展していくのが観察できる.

\section{2 シャフトをスキーポールとして使用し たときの衝撃エネルギーの推定}

実際にシャフトをスキーポールとして使用し たときのスキー板による衝撃エネルギーを推定 するため, 使用状態を実験室内で再現L, Fig. 6 のアルミニウム合金シャフトの傷の最大深さと の関係から衝撃エネルギーを求める。このとき の損傷の発生要因としては, 一つは「滑走中に シャフトとスキー板が衝突する」ももう一つは「シ ャフトでスキー板の雪をはらう」ような場合を 想定する.

以上の条件から求めた, 衝撃エネルギー量の 発生頻度を Fig. 8 に示寸。同罒から, 実際に発 生する衝撃エネルギーは, ほとんど $0.05 \mathrm{~J} \sim 0.3$ Jの範囲に集中しており，スキー板との衝突の 場合は, 頻度は低いが衝撃エネルギーが $1.5 \mathrm{~J}$ 程 度に達することもある。

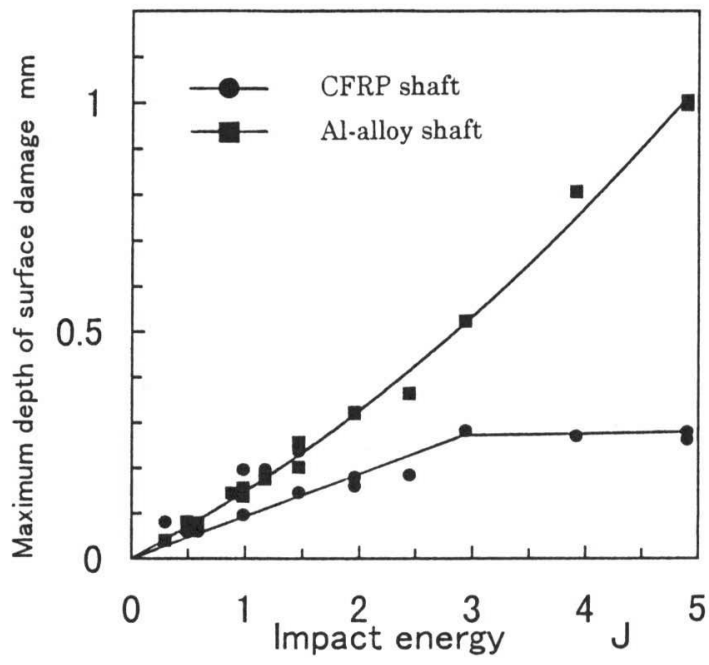

Fig.6 Relationship between maximum depth of surface damage and impact energy

\section{3 曲げ試験における衝撃損傷の影響}

次に, シャフトの曲げ強度について, 衝撃工 ネルギーと破壊荷重の試験結果から議論する. 衝撃損傷を付与した後のアルミニウム合金シャ フトと CFRP シャフトの三点曲げ試験と四点曲 げ試験の破壊荷重の結果を Fig. 9 に示す。両試 験結果から，破壊はすべて損傷を与えた圧縮側 で起こっている.

四点曲げ試験結果から，衝撃損傷のない場合 の破壊荷重は, CFRP シャフトがアルミニウム 合金シャフトに比べ高く, 衝撃エネルギーの負

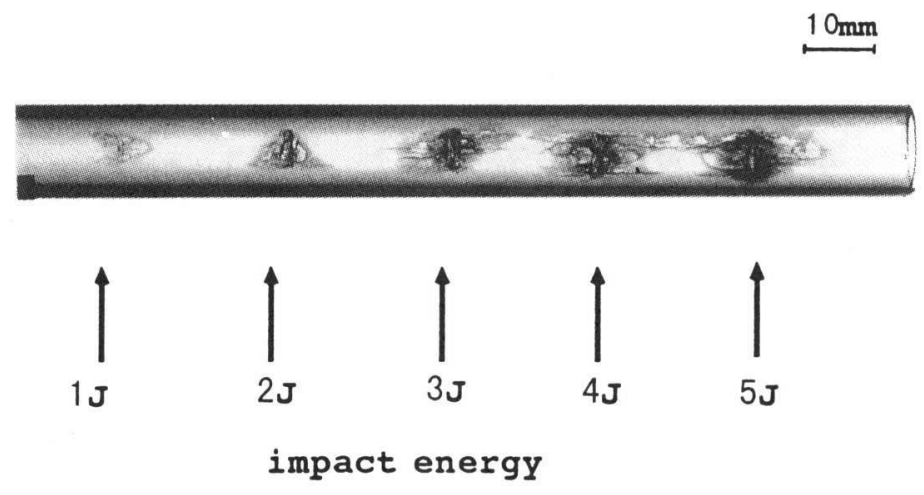

Fig.7 Photograph of damaged surfaces observed by X-ray 


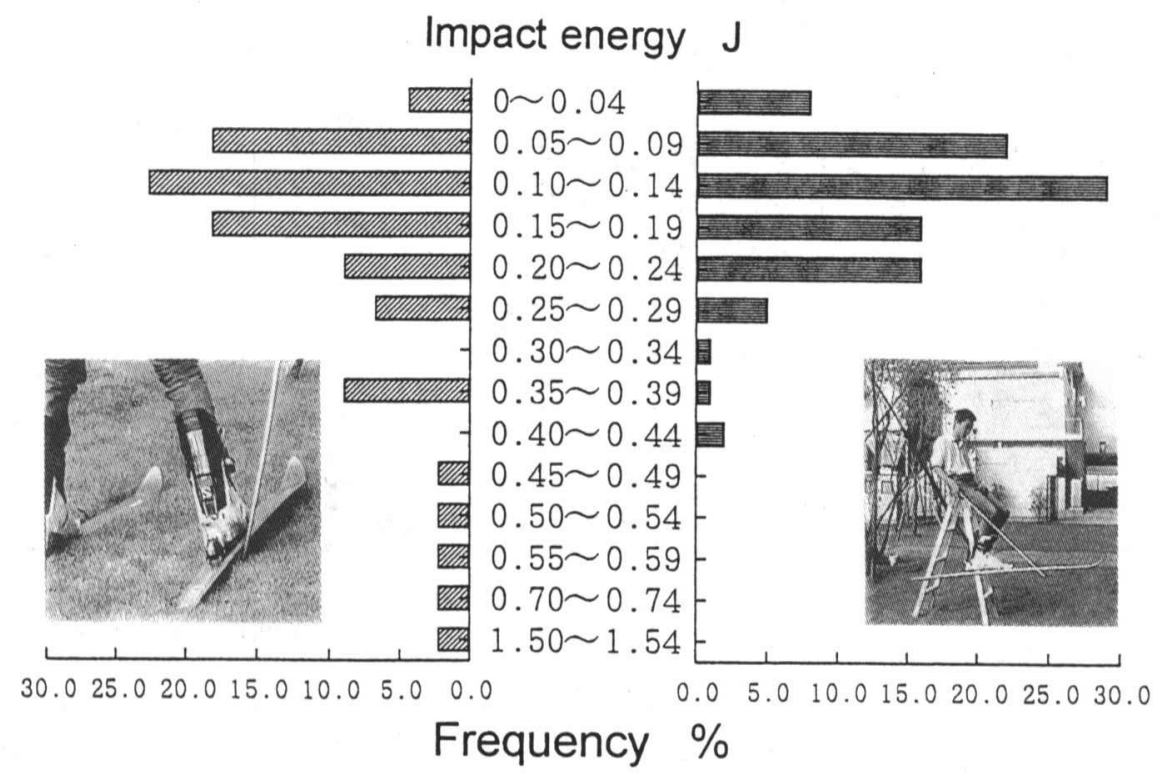

(a) In case of collision

(b) In case of tapping

Fig.8 Distributions of impact energy generated by ski pole and plate

荷とともに急激に低下し，50\%以下となってい る. 衝撃エネルギーが1J 以上になると, 破壊荷 重は漸減し,アルミニウム合金の場合と同じよ うな傾向を示している.このことは, CFRP シ ヤフトの破壊現象がアルミニウム合金のそれと は異なり，僅かな内部損傷が存在していても残 存強度に大きく影響することを示している.

一方, 三点曲げ試験の結果から, 両シャフト の破壊荷重は, 四点曲げ試験結果に比べて低く なっている．これは，中央の荷重点に応力が集 中することから，その部分での座屈破壊が発生 することによることを示している．特にその傾 向は, CFRP シャフトの衝撃エネルギーが負荷 されない場合に顕著である。

以上のことから, シャフトの曲げ試験は四点 曲げ試験が適しているが，スキーポールのよう なテーパが付いた場合は四点曲げ試験が困難な ことから, 衝撃エネルギーが1J 以上負荷された 場合には, 三点曲げ試験が有効であるといえる. このことから, 以後の曲げ試験結果の議論は三 点曲げ試験にて行う。
次に, CFRP シャフトでは微小な内部損傷が シャフトの破壊荷重に大きな影響を及ぼしてい ることが Fig. 9 からも明らかであることから， CFRP シャフトに静的な損傷を与えて曲げ試験

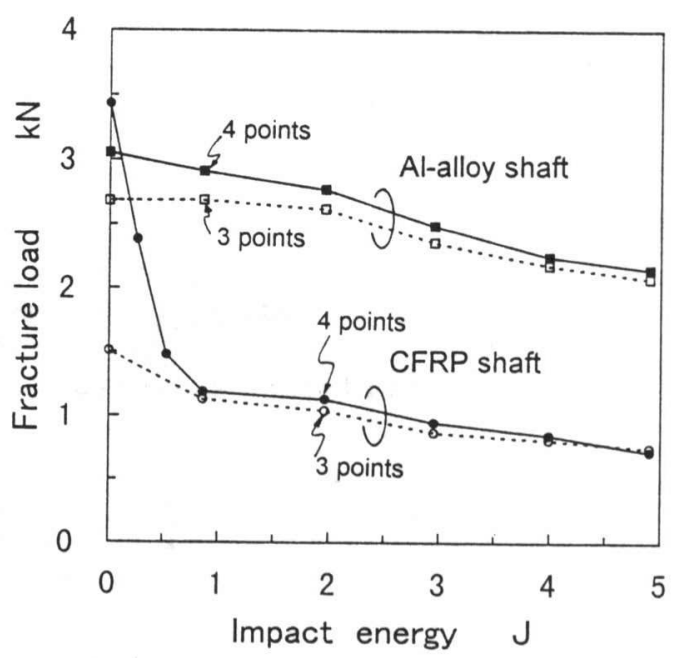

Fig.9 Relationship between fracture load and impact energy in bending tests 


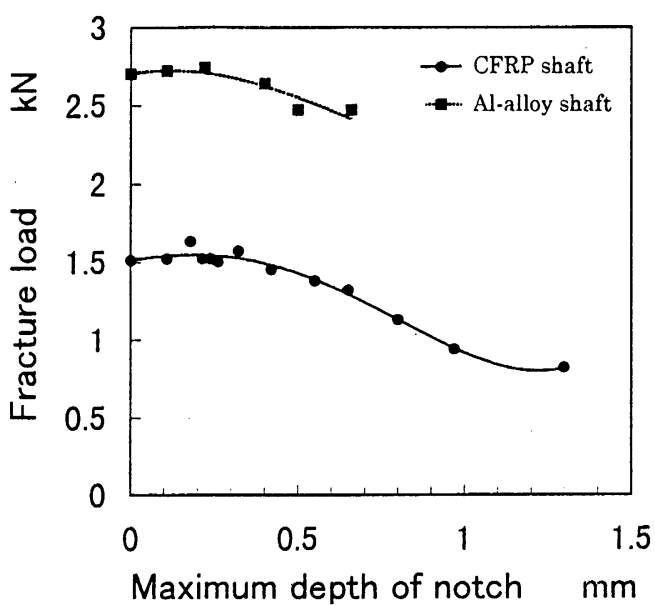

Fig.10 Relationship between bending fracture strength and maximum depth of notch formed by file

を行う．静的損傷の負荷は, ヤスリの角でシャ フトの円周方向に削ることによって行い, その ときのシャフトの損傷状態をX線透写真により 観察すると, 静的な損傷では層間剝離の内部損 傷は見られなかった。この静的損傷を与えたシ ヤフトの三点曲げ試験を行う. 付加した静的損 傷の最大深さと破壊荷重の関係を Fig.10に示す. 同図から,傷の染さが $0.3 \mathrm{~mm}$ 程度までは破壊荷重 が低下しない. 付加した損傷の深さと Fig. 5 の 衝撃損傷深さを対応させると, 衝撃エネルギ一 は約 $2 \mathrm{~J}$ となる。これらの結果から, CFRP シャ フトの著しい残存強度の低下は, 材料の外傷の 深さでなく，内部損傷の進展が起因している。

\section{4 ポストバックリング試験における衝擊 損傷の影響}

スキーポール使用時に軸線上に過度の荷重が かかり，ポストバックリングの状態になると， アルミニウム合金の場合, シャフトの中央部か ら屈曲する。しかし, CFRP の場合, 塑性変形 を起こさないため, 典型的分離破断する場合が 多い.ここでは，CFRPの衝撃損傷による変形 量の減少と破壊の特徵について議論する.

衝撃損傷のない CFRP シャフトの軸線方向に

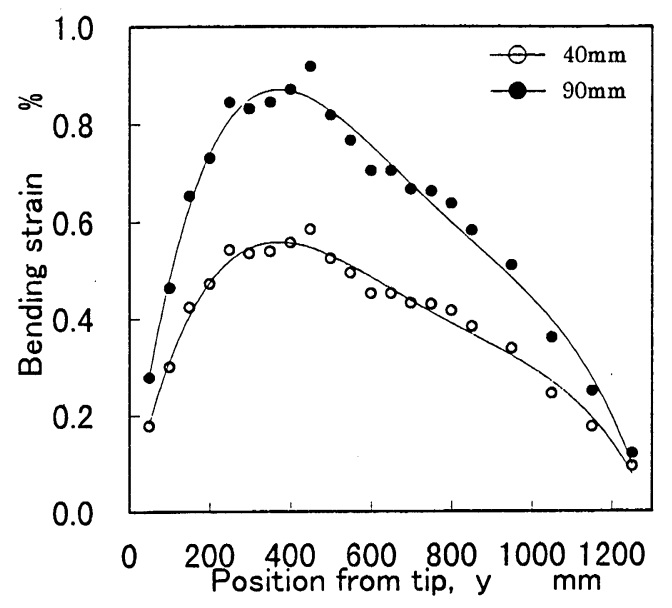

Fig.11 Relationship between bending strain for buckling displacement of 40 and $90 \mathrm{~mm}$ and position from tip of undamaged CFRP shaft

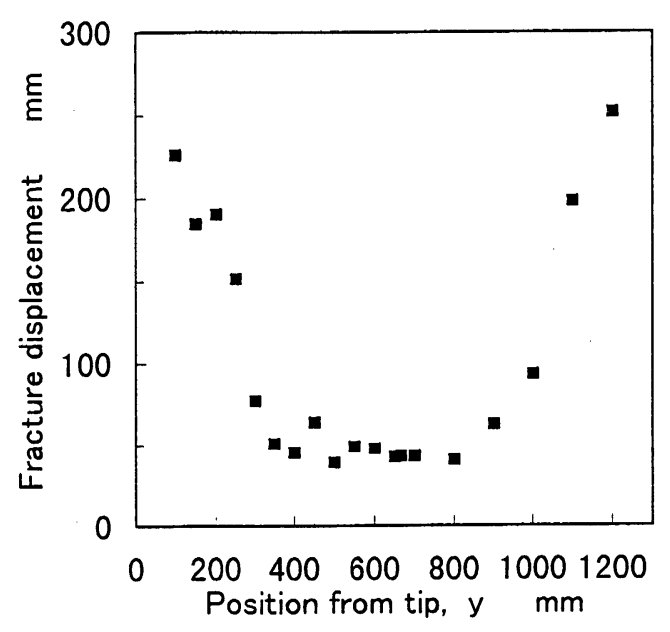

Fig.12 Relationship between buckling fracture displacement and position from tip of CFRP shaft damaged with $0.9 \mathrm{~J}$ in impact energy

貼付したひずみゲージの出力から，ポストバッ クリング時のシャフトの各部のひずみ量を Fig. 11に示す. 同図から, 最大ひずみの個所は石突 きからの軸線位置が $300 \sim 400 \mathrm{~mm}$ の範囲で, テー パ部にある. 次に, $0.9 \mathrm{~J}$ の衝撃エネルギーを 1 個所付加した CFRP シャフトを用い, 損傷部分 
を圧縮側に配置してポストバックリング試験を 行う。損傷を与えた軸線位置と破壊に至るまで の変位量の測定結果を Fig.12に示す. 同図から, 軸線位置300〜800mmの範囲に損傷を与えた場合, いずれもバックリングの変位量が40～ $50 \mathrm{~mm}$ と小 さく,シャフトの変形が小さな場合においても,
損傷部からの破壊を起こしている。ここで，衝 撃損傷部を圧縮側へ配置した場合は，全て損傷 部から破壊を起こしている。これに対し，衝撃 損傷がないシャフトの場合は, 変位量が平均 240 $\mathrm{mm}$ 程度で破壊し，破壊箇所は最大ひずみ点の個 所付近にみられた。このように, シャフトの破

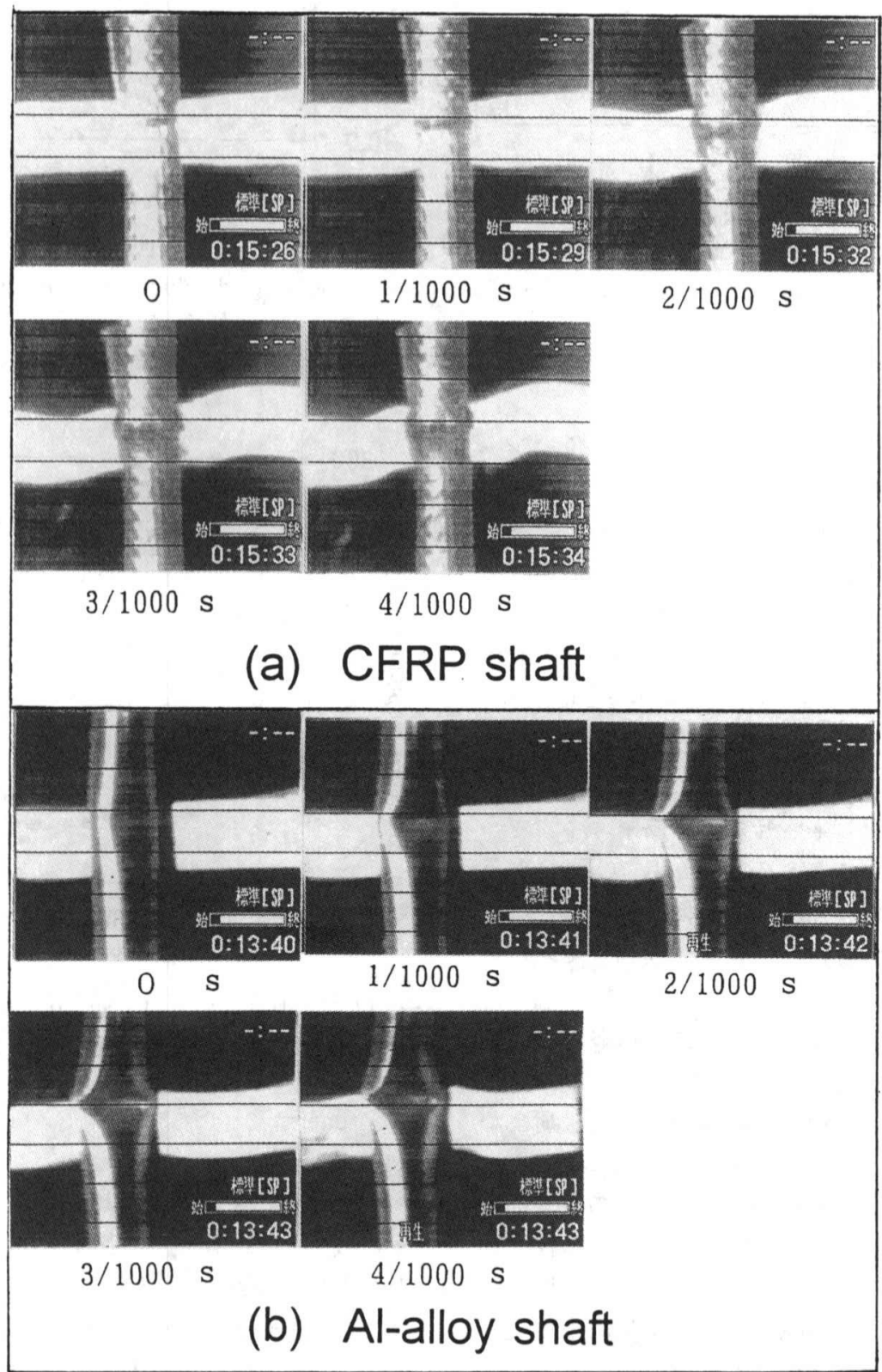

Fig.13 Fracture phenomena of 2 shafts observed by high-speed camera 
損は損傷の有無に依存していることを示してい る.

次に, 衝撃損傷部を引っ張り側へ配置すると, 損傷部からの破壊はみられず，破壊に至るまで の変位量は低下しない.しかし, シャフトの破 壊状況は，3 分割以上の分離破壊を起こすこと もある。

これらの破壊の観察は，高速ビデオ装置によ つて行う.0.9 J の衝撃エネルギーをシャフトの テーパ側先端から $400 \mathrm{~mm}$ の位置へ付加し, 損傷個 所がポストバックリングによって破壊する現象 の結果を Fig.13に示す.アルミニウム合金シャ フトの場合は屈服破壊がみられるが, CFRP シ ヤフトでは，衝撃損傷個所での圧縮破壊がみら れ, 破壊形態が明らかに異なっている.CFRP シ ヤフトの破面は破断した繊維が鋭く, スキーポ 一ルとしては危険性が高いといえる。

\section{4. 結言}

本論文では，最近使用量が多くなってきてい るスキーポール用 CFRP シャフトについて, ス キー滑走中に生じる衝撃損傷によって起こる強 度低下を従来のアルミニウム合金シャフトと比 較することによってその原因と破壊の特徵を明 らかにし，強度低下を評価できる試験方法を提 案した。

CFRP シャフトは，スキー板との衝突によっ て与えられると思われる1J 程度の衝撃エネルギ 一によって破壊荷重が50\%以上の減少がみられ， ポストバックリングでの破壊までの変位量が約
80\%減少する. CFRP シャフトの強度低下は, アルミニウム合金シャフトと異なり，層間剝離 の内部損傷が主要因であることがX線透過写真 や静的損傷付加実験から明らかである。ポス卜 バックリングでの CFRP シャフトの破壊は, ア ルミニウム合金シャフトの屈服破壊と異なり, 衝撃損傷個所での圧縮破壊であることを示して いる.

スキーポール用シャフトの評価に本試験方法 を用いることにより，スキーポールへの CFRP シャフトの導入に際し安全性の向上が促進され るが, 最も重要な課題は，ポストバックリング における分離破壊防止対策法を開発することで あるといえる。

謝辞：本研究を進めるにあたり, 実験に協力し て頂いた信州大学繊維学部 (現, 新光電気工業 (秼)）北島正邦氏，また試料の提供を頂いた侏シ ナノ様はじめ長野県スキー工学研究会の会員各 社に深謝します。

\section{参 考 文 献}

1）例之ば，荻原慎二，他；CFRP 積層板の落錘衝撃に よる微視的損傷と残留圧縮強度, 日本機械学会論文 集(A),Vol.63, pp.145-150,1997.

2) ISO7331-1983(E) ; Ski-poles for alpine skiing Safety requirements and test methods,1983.

3) Varadan,T.K.and Prathap,G., ; Inelastic PostBuckling of Tapered Flexible Bars,Computers \& Structures,Vol.21,pp.681-686,1985. 